\title{
Iulia CÎRDAN
}

\section{Melancholia as a Perpetual State.}

\section{Configurations of Memory and how the Process of Becoming Becomes Externalized in Cinematography} \begin{abstract}
rather than shows. will focus mostly on Nuit et brouillard and Hiroshima mon amour as they envision this perpetual state of melancholia. The second part of the paper will address the subject of memory, affect and becoming, as seen in relation to identity and the way characters are situated in a space in between, nameless and open to development and to new possibilities.
\end{abstract}

Abstract: The paper focuses on the way melancholia can be rendered visible in movie while perceived as a perpetual feeling - an affect in Deleuze's terms. Existential crises, horrors, traumas and the unavoidable quest for truth are all tackled by Alain Resnais; the paper strives to analyse the way colours (or lack thereof) are used so as to give rise to a perpetual - yet ephemeral - feeling of melancholia. This paradoxical view is at the core of Resnais's movies and enables the appearance of haecceties - elements which give a sense of uniqueness to the movie - at the intersection of corporal and non-corporal elements. Resnais' cinematography goes on the same line on which Picasso imagines painting: Painting is a blind man's profession. The painter paints what he feels and not what he sees. Similarly, Resnais seeks to create cinematography that suggests

Melancholia occurs at the meeting point of time and space in Resnais' cinematography, coordinates which, once intertwined, greatly influence the characters' configuration, the imagery and the sound. The paper

Keywords: melancholia, identity, art, memory, becoming, affect.

\section{The role of (lack of) colours and sounds in creating an affect}

The whole description of our landscape and the lines of our universe, and of our inner monologue, needs to be redone. Colors, sounds, and things - like

\section{Iulia CÎRDAN}

Babeș-Bolyai University

iulia.cirdan19@gmail.com

EKPHRASIS, 1/2019

A Melancholic Exploration of Humanity

(The Solitude of MAN)

pp. $198-210$

DOI:10.24193/ekphrasis.21.14

Published First Online: 2019/06/27 
Van Gogh's stars - are the focal points and radiance of being (McLeary, 15). Both movies by Alain Resnais rely on colours to create sensations - described by Deleuze as a lived passage from one state to another that is irreducible to any state (Deleuze 1978a). Hiroshima mon amour and Nuit et brouillard approach traumatic events, such as the Holocaust, described by Maurice Blanchot as the absolute event of history - which is a date in history - that utter burn - where all history took fire, where the movement of meaning was swallowed up (33) and which dramatically changed the structures of the real as we know it. The main aim of cinema is, as Montebello suggests: to have an effect of shock on thinking and force thinking into reflecting upon itself and upon everything, something that stands for the definition of the cinema and of the sublime (48).

Colours are used differently in painting, cinema, photography and literature (if we are to consider descriptions of colours as their representation as well). In contrast with painting, cinematographic image implies movement, which denotes time and is made visible through time: the cinematographic image [...] extracts things from the mobility of movement, but - as Deleuze puts it - this reference to time is invisible to the viewer, as we see only the effect of the time in space, only movement itself as if constituting an indirect image on time (28). This indirect image is generated at the point of intersection between visual and audio methods, between chaotic tracking shots and lingering close-ups. The similar effects colours produce are discernible once analysing their ultimate purpose. By taking a look at how colours are used in art and the way they are linked to different sensations, there are some similarities with cinema we should acknowledge - as they also reveal how internalized emotions become exteriorized through colours and transgress time and space. Analysing, for instance, Selfportrait by Parmigianino - an Italian mannerist painter from Florence we are struck by the powerful sensation the painting conveys by way of using blurred contours through which melancholia emerges - similarly to the feeling transmitted by Resnais' characters.

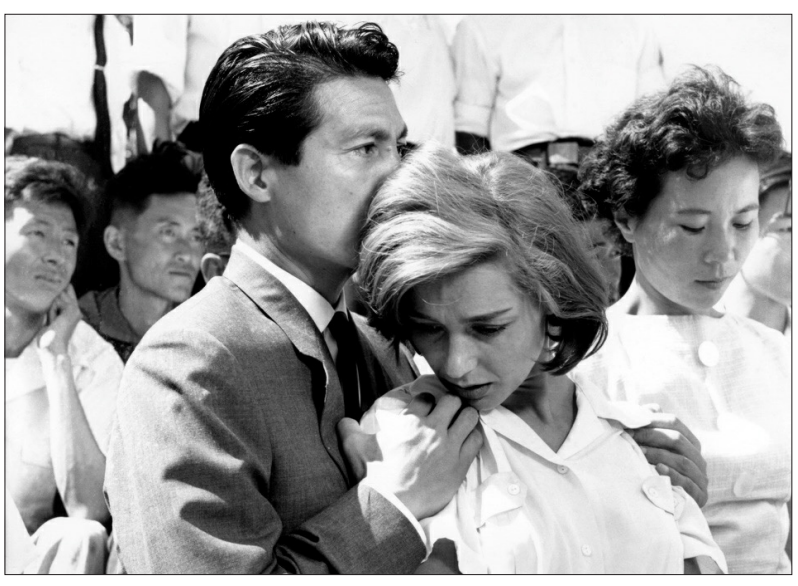

Rialto pictures

Van Gogh often uses the colour yellow in order to depict himself at unease similarly to Fassbinder it in the movie Ali: fear eats soul.

The scene depicted represents the moment when Ali and his lover seek to make their relationship public and hope to be accepted by society. Their case is challenging: they are completely marginalized and become outcasts of their families and society 
as it is inconceivable for people that a German middle-aged women could be together with a young immigrant. By positioning the yellow, unoccupied chair right in front of us, we became conscious of the importance held by the absence of others - in this case the absence of society and its understanding.

This melancholic state can be rendered visible by using less defined shapes and colours, but whose vibrations produce

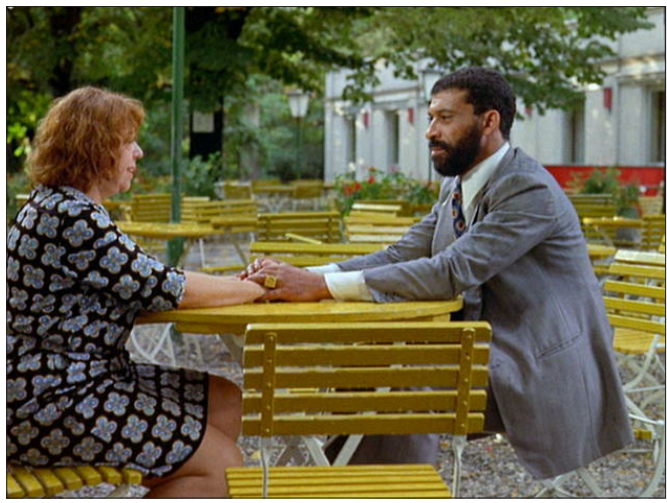
similar effects. If we take a look at the painting Hiroshima by William Wright we can notice that his painting figures the role of abstraction in illustrating a traumatic event, following Bazin's principle of choosing the personal factor in artistic creation as a standard of reference (Bazin, 1985), through which artists manage to paint the scream more than the horror in Francis Bacon's terms (51).

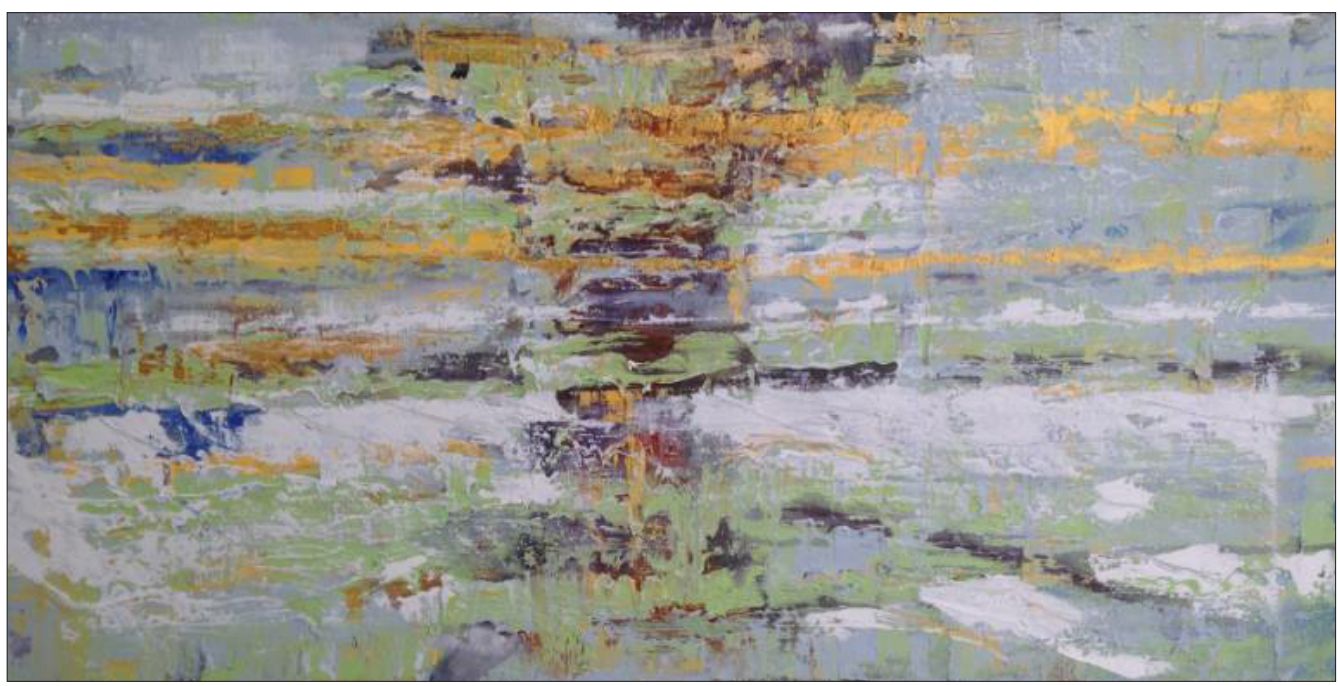

In another painting by William Wright - Mind: Blown - the artist uses blue in order to suggest that man is open to new possibilities, to becoming, to multiplicity. Van Gogh's Irises - a work created during his sanatorium period - captures a sense of melancholia at the intersection of colours transfused ever so gently so as to create an affect. Colour has always been used in painting as a way to transmit emotion and to show subjectivity - as Merleau Ponty envisions: Between the alleged colours and visible, we would find anew the tissue that lines them, sustains them, nourishes them, and which for its part is not a thing, but a possibility, a latency, and a flesh of things (Ponty, 46). During his blue period, Picasso focuses mainly on portraying poor or desolate people, sick 
people, drunkards - those situated at the margin of society, such as the painting Blind's man's meal from 1903 portrays. The character's faces create an atmosphere of dissolution, dissipation from reality through which melancholia emerges on canvas and brings into visibility pure intensities and images (image-affect) that speak to our humanity and relate to the way we perceive the world.

Alain Resnais appreciated the way artists perceived the world and their attempt at re-conceptualizing the limits of the universe through their work. He proved his admiration in Guernica - a movie which suggests the devastating effects of war by focusing on the assault on the Basque Country town in Spain, Guernica. Using Picasso's paintings, the movie postulates that abstract art is relevant as it brings into visibility the unimaginable, the unexpected, the unthinkable. Apart from the visual aspect, the movie also offers a powerful message: Actors in a perpetual drama, you did not expect death. Fused with the music by Guy Bernard and the voice over that explains the events, the paintings acquire a new meaning which is to present that the seemingly distant disaster is now at our doorstep: Somewhere in Europa the army is marching over humanity, somewhere in Europe, and it comes at our doorstep. This view goes on the same line with Maurice Blanchot' claims about disaster perceived as something that takes care of everything (7) and which re-writes the coordinates of the world as he explains: The disaster ruins everything, all the while leaving everything intact. It does not touch anyone in particular; "I" am not threatened by I [...] the disaster threatens in me that which is exterior to me - an other than I who passively become other (15). Passivity, suggests Blanchot, also represents a way of perpetuating terror, as lack of resistance entails acceptance. In this context, the efforts of those who have struggled to resist by using the lingering potential inscribed in art are remarkable. The director decided to show the trauma of the Second World War and its effects through the personal trauma of the couple who meet in Hiroshima. Resnais initially attempted to create a documentary 12 years after the bombing in Hiroshima, but abandoned the project several months later for reasons expressed by Marguerite de Duras: One can only speak about the impossibility of speaking about Hiroshima. The knowledge of Hiroshima being, at the outset, presented as an exemplary delusion of the mind (Duras, 1961).

Deleuze described the affect as a collective emotion relevant to humankind. In Hiroshima mon amour we can notice the concept of concrete universality at work, as it becomes clear why Resnais chose to present universal trauma through the personal distressing events lived by the characters. Following a Hegelian line of thought, we realize the importance of speaking subjectively while having universality as an ultimate purpose. Resnais' cinematography stands for the "part of no part," those with no proper place within the social edifice [that] are directly the universality of "people" - as Žižek puts it. In order to obtain this effect, Resnias uses only black and white tones in his documentaries: The white or black screen, 'is the interstice made visible' (Bogue 2003a: 179). The lack of colours - or, rather, the image captured in black and white - is the 
only conceivable way of revealing the truth about the death camps, keeping in mind that no description, no image can reveal their true dimension (31). It is only through lack of colours that one can present a traumatic event and Resnais acknowledges being the first to use black and white images to capture the atmosphere of the death camps and speak for and about the 9 million people who perished there.

The images in Hiroshima mon amour should be analysed in relation to the sounds in order to grasp the whole effect the movie renders, as Boljkovac states: This visual image [...] evokes a rhizomatic surfacing upon an unknown surface, a mysterious formation perceived against a strangely agitating soundtrack (61). As in his other movies, the soundtrack plays an important role, forms a circuit and creates movement together with the image. The piano in the beginning of Hiroshima mon amour initiates the melancholic tone, which is further articulated by the close-ups of bodies entangled in a dance of love, death and life. The role of sound is though best seen in its absence: here was a fearful silence, attests Hiroshima writer and survivor Yoko Ota - which made one feel that all people and all trees and vegetation were dead [...] silence the only sound the dead could make' (Rhodes 1986, 715). Maurice Blanchot claims that what we are left with after the Holocaust is the fleeing silence of the countless cry (33). He explains: And to be silent is still to speak. Silence is impossible. That is why we desire it (25). The sound and the voices are important for Resnais as he did not accept to make the movie until he was able to have one of the survivors of the death camps - Jean Chirol - narrate the story. The movie makes us conscious of our position and of our reaction when confronting death: We turn a blind eye to what surrounds us and a deaf ear to humanity's never-ending cry writes Marguerrite de Duras in Nuit et Brouillard. It is our duty to at least allow ceaseless cries be heard - which also represents one of the aims of movie making: And as a camera tracks along the French countryside and river[...] the film's soundtrack[...] remains in Hiroshima (Boljkovac, 86).

\section{Time, perception and montage in cinema}

Alain Resnais reflects upon the possibility of rendering visible traumatic events - such as the Holocaust or Hiroshima's nuclear explosion - in order not to abuse the victims' distress and to leave room for reflection. One option lies in creating a space of continuous becoming that ultimately gives rise to melancholia transposed at a cinematographic level. The way Resnais tackles the subject of horror is by suggesting, rather than by showing, due to the fact that the director sought to engage the viewer in an imaginary journey - similarly to how Alain Badiou envisions cinema: cinema does justice to the human figure inscribed in the contemporary world; [...] cinema as an imaginary voyage and a thinking of the Other (3). Resnais' movies encompass both a personal and a universal vision, which is perceptible once we analyse the film's imagery - as Nadine Boljkovac points out in Untimely Affects: images [...] - relive, reactivate and resituate the atrocities of Hiroshima in both personal and universal dimensions, as both an individual scar and geographical map (3). 
Resnais's movies create a different temporality than that we have been accustomed to and that follows Gilles Deleuze's views on cinema and philosophy: philosophy has always been an interior cinema, and cinema the modernised and technological derivative of the philosophical method (Montebello, 10). Philosophy becomes exteriorized through cinema, which makes visible thoughts and mentalities that linger in our consciousness: nous faisons du cinéma sans le savoir (Montebello, 10). Similarly, time should not be perceived as something interior to us, but rather as something in which it is us who become internalized, in which we move, live and change (115). Reiterating Deleuze, Nadine Boljkovac states that cinema is a phenomenon more radically revelatory of time and space than any other art (23), hence figuring that intensities, perceptions and sensations are perceptible through this art of auto-temporalization and self-movement as Deleuze refers to (58), by inferring that cinematography creates a different sense of reality than that provided by our eyes and which is to be judged accordingly.

When it comes to the way cinema makes affects visible, it is important to take into consideration not only the visual and sound effects, but also to reflect upon the overall picture which brings all elements together: the montage. Cinema is strongly related to the process of image creation, an absolute movement brought into Universe, perpetual creation (durée) (Montebello, 19). Considering what Merleau Ponty claims about cinema - as the art which shows itself as art, montage and process - we can establish a connection between abstract art and cinema: There is a necessary rupture in art which is entailed by abstraction. This rupture is envisioned by Paul Klee when he speaks about the function of art: to make visible and not to show what already is visible. As the reality of the painting is made on the canvas - according to Cézanne - the reality of the movie is made on screen: neither the drawing nor the picture belongs to the in-itself any more than the image does (Toadvine and Lawlord, 356).

\section{Configurations of identity}

Identity is another concept the movie tackles, deemed as something that encompasses different potentialities and opportunities of expression. Identity is a word that comes from latin idem, later used as identitatem in Medieval Latin which came to English during the $16^{\text {th }}$ century and has been used ever since with the meaning of being the same, following the same coordinates. It thus becomes clear why Alan Resnais chose not to offer a proper identity to his characters. The two lovers from Hiroshima mon amour do not even have a name, they are referred to by using the personal pronouns $I l$ (he) and elle (she). Resnais implies that the characters do not have a stable, fixed identity, but are forever moving towards other forms of becoming, as the images suggest: Cinematic time images open to non-hierarchical, virtual becomings, affects and percepts of worlds other than those that can be recognised, a time of difference initself, an untimely time that brings only the new, the eternal repetition of the different (15). In one scene, the male character tells his lover that he wished he could find out more about her younger self - the moment where she did not belong to anybody and was 
not influenced in any way by others. His statement is relevant for what Deleuze calls pure intensities and pure affects. In Eric Rohmer's Le genou the Claire, the man's desire though triggered by something tangible in reality (the knee) - does not imply action and thus becomes pure desire. In a similar way, Resnais's movies are centred on creating pure states of melancholia, through constant becomings and intensities. This is why the director chose to free the woman from all confines of identity or fixed traits society has burdened her with: being French, woman, lover, wife, daughter all proved to be demanding, severally influencing the course of her life and her decisions. Once deprived of the limitations imposed by these categories, the woman transgresses all roles that have been given to her and eventually becomes free. Through this act of depersonalization and deteritorrialization, she ends up being impersonal, yet more discerning, aware, yet more on the edge - something that does not make her existence less lively, as according to Deleuze, the most beautiful thing is to live on the edges. She follows a line becoming which Deleuze suggests has neither beginning nor end, only middle, as she pursues a state of perpetual melancholia through her reminiscence of a time passed. Maurice Merleau Ponty states by referring to identity: There is not identity, nor non-identity, or non-coincidence, there is inside and outside turning about one another (123).

The characters become the space and time they are referring to: Hi-ro-shi-ma. That's your name,' to which he replies 'that's my name. Yes. Your name is Nevers. Ne-vers in France' (Duras, 1961). Julia Kristeva refers to this type of identity as free individuation allowing characters to transgress the limits given by their nationality, gender or social status. It is through cinema that potentialities come into visibility, as Deleuze argues: Cinemal...]possesses the potential to free thought and life from confinement, if only temporarily, through the liberation of affects and the 'creation of a people' (255). The process of becoming describes the characters' course of life on screen. Not only does she become one with her lover and one with the place she describes (Nevers), but she also enters a state of becoming animal when encountering a cat - while recollecting her time in the cellar, when punished by her father for her previous love affair. Likewise, the perception on cinematography should be expressive of the relation between humans and the universe: Tout est vision, devenir. On devient univers. (Montebello, 90).

Names are significant when addressing the concept of identity and they acquire another significance in Nuit et brouiallrd, as strongly relate to collectivity and are infused with a certain callous feeling, as the unruffled voice-over utters: Strüthof, Oranienburg, Auschwitz, Neuengamme, Belsen, Ravensbruck, Dachau' (NB), as the camera, [the] 'only visitor' [...], releases pure affects of emptiness, barrenness, coldness and harshness (Boljkovac, 36). A process of depersonalisation takes place, as we cannot distinguish one inmate from another, one dying face from another: the nameless spectre bears only its designation, 'N.N.', an abbreviation, as survivors testify, for both 'Nacht und Nebel' and "NOMEN NESCIO - "name unknown" (Raskin, 16). In a similar way, Hiroshima mon amour shows images of prisoners remaining faceless while approaching in death, 
changing the configurations of human: This depersonalisation of the inmate, so shockingly shameful, defaces the notion of human as it opens towards a becoming-imperceptible, a nonpersonal individuation (41). By comparing the two movies, we can notice how death upsurges as a key point in Resnais cinematography. Death offers a contour, a turning point, that links traumatic events and expounds the relevance of memory in preserving and creating the event, as reminiscence is a process that entails constant reconfiguration of the real. Death opens the way for haecceities - understood as that which is no longer[an act] of individuation but of singularization', [...] to a man who no longer has a name (Boljkovac, 70). Rithy Panh - the Cambodgian director and survivor of the Khmer Rouge who directed the movie S21 - is also aware of the presence of death in the movie, as he claims upon seeing Nuit et Brouillard: It was the same thing. It happened elsewhere. Before us. But they were us (Panh 91). Death can be perceived as the way through which we can be reborn - death as the means through which we appreciate the will to live: Nuit et Brouillard defies not only threats of forgetting and denial but also [...] challenges death with life (Boljkovac, 35).

Identity is linked to emotions, sensations and perceptions and can be seen in relation to melancholia - which is close to the concept of becoming cinematography displays. Although confined to a specific moment, it transcends space, time and being similarly to how cinema creates and interiorizes temporality. Melancholia - as a state characterized by inbetweeness and ambiguity - often met disagreeing views. In $A n$ Essay on Abjection Julia Kristeva suggests that what causes abjection is that which is associated with the in-between, the ambiguous, the composite [....] because it draws attention to the fragility of the law and therefore troubles identity. Melancholia has a similar effect as it encourages constant enquiry and questioning of fixed traits. Hiroshima mon amour is characterized by the gloomy, fluid atmosphere in which the characters escape the attempt of being caught in hierarchies, following Nietzsche's principle of imagining art as transcending the limits imposed by ideologies and morals. The characters from Nuit et Brouillard, on the other hand, are victims, bodily effects of a systematization: 'Shaved. Tattooed. Numbered. Caught up in some incomprehensible hierarchy' (34) and should become a body without organs - in Deleuze's terms - in order to regain their humanity.

Rembrandt uses self-portraits in order to speak about humanity. By portraying himself as Saint Pavel, the painting suggests that identity is not written once and for all and that through experimentation our being acquires new significations and potentialities. Some of his portraits envision the artist in a melancholic position like Autoportrait au beret à l'écharpe le visage sombre - in which the image depicted, the colours used and the affect thus revealed is comparable to the melancholic effect produced by Bergman's Herbst Sonata. Paying attention to the way the director uses the colour orange, the fusion between faded and vibrant colours in order to highlight the nature of the feminine character, it becomes clear that it is throughout the encounter between her and the other characters, the landscape and the colours, her and the light, that the melancholic tone is expressed and made visible and the feeling 
of alienation transmitted: Throughout these encounters, the film appeals to our senses, to our imagination: In whichever tone, its primary characteristic is that it can only be sensed (Boljkovac, 65).

\section{On (non)corporality. \\ How bodies emerge on screen}

A philosophy of the surface and of the event is always caught in a struggle with violent and destructive mixtures of bodies; it is always trying to give sense to a life of violent shocks, invasions and punctures (Williams 2008a: 84). The violence Williams refers to is rendered visible in Hiroshima mon amour through the love affair of two characters, about whom Marguerite de Duras claims: It is not the other which is another I, but the I which is an other, a fractured I (Duras, 261). This ideal is reiterated throughout the movie, as the characters constantly become an Other and meet at the intersection of time and space, through memory and recollection.

The question of non-corporal elements, objects having the potential of becoming works of art has been timely recurrent in art and is relevant for cinematography as well. Merleau-Ponty claims about the body: Visible and mobile, my body is a thing among things; it's caught in the fabric of the world, and its cohesion is that of a thing. But, because it moves itself and sees, it holds things in a circle around itself. Alain Resnais shows the body by making use of extreme close-ups, various angles and by alternating images of the bodies covered in ash with bodies covered in sweat and thus creating an aesthetic revolution - in Rancière's terms. The body speaks about death (through ashes) and life (through sweat) and encompasses a constant shift of the boundaries between visible and invisible, real and imaginary: The feeling affect (joy or sadness)[...], 'follows from the image affection or idea that it presupposes, of the body that agrees with ours or does not agree (Boljkovac, 86). Resnais's movies are situated in a space in-between through which new possibilities emerge. In order to reiterate the importance of becoming and of the non-human element, it is important to observe how the meaning of humanity changes throughout both movies: I saw human bodies in such a state that you couldn't tell whether they were humans' (Rhodes, 723). Rithy Panh shows in his movies that when humanity is no longer recognised, torturers gain full power and relate to their victims as if they were pieces of wood. Resnais's movies often refer to traumatic events which have re-written the course of history. In Nuit et brouillard the images show an ethical perspective of the Shoah event. By way making all victims look similar, with no individuality whatsoever and no difference in their looks - as the eyes are the locus of emotion and which pertain the same detachment from reality - the movie captures the reality of the event. They do not look human because their humanity has been deemed unnecessary. The images are similar to those captured in Hiroshima mon amour, where the faceless death are caught on screen and reiterate the idea of perpetual becoming. The image of death is burdening as Rithy Panh puts it: these terrible deaths affect us and should affect us. Hiroshima mon amour highlights the way in 
which death can shape and re-shape our way of thinking. The images in the beginning of the movie are relevant as by way of using close-ups and unfamiliar angles they show the way death can make everything look similar: The images are no longer linked by rational cuts and continuity, but are relinked by means of false continuity and irrational cuts (Deleuze, 11). Touched by death, the bodies become one, like stones and dust: People become like stones, stones become like sand, sand becomes dust, similar to sweat drops. The image takes care of everything and the movie exceeds the limits imposed by history or any other fixed frames of thinking.

That which opposes death is situated on the instinctual level - the sexual desire - depicted in Hiroshima mon amour. Resnais' movie insists on the relation between these two instincts (of death and of life) by portraying bodies caught in the act of love making side by side to bodies engaged in a dance of death. The purpose of the body becomes multiple: Even the body is no longer exactly what moves; [...] it shows time through its tirednesses and waitings. The body becomes the embodiment of death and life: Hiroshima mon amour stands as a series of affective becomings, and surface intensities between actual and virtual, body and thought, 'Nevers and love', 'Hiroshima and love' (Duras, 12). The characters from Nuit et brouillard have become simple actors whose faith has been decided beforehand: Le personnage est devenu une sorte de spectateur dans le film (Montebello, 91). We can perceive characters as spectators of their own lives, as Resnais brings to our view in a simple - yet complex - view: as the lovers of Hiroshima mon amour lose themselves through their encounters and sensations, through the intensity of a singular love, the film's body, with that of the lovers', opens to unknown possibilities (63). Characters are, from this point of view, spectres that capture a sense of nostalgia, and the movie becomes situated at the border: between timely and untimely, melancholia and nostalgia, being and non being. This inbetweeness characterizes the movie and leaves room for alienation - similarly to how Deleuze characterizes the percept: The percept is the landscape before man, in the absence of man (57).

\section{Memory and reminiscence as duty}

We 'live' when we cannot remember. For only when our sensory-motor extension remains suspended and the actual image 'enters into relation with genuinely virtual elements' can time, the virtual past and the 'birth of memory, as function of the future', emerge (Deleuze, 167).

In Hiroshima mon amour each character has its own memory, but they are not intersected as in Last Year at Marienbad which means that the characters are forced to live the events through the recollection of the others, without having witnessed them themselves: Hiroshima and Nevers, two dissimilar places at the intersection of which the two characters meet (through each other's memories). Memory is depicted as collective memory rather than memory that belongs to individuals - world-memory - which gives rise to haecceties. These are singular events that connect the movie to 
the exterior reality, enhancing the concept of a concrete universality: The haecceity is the fact that it occurs as an event, but when it emerges, it has always-already been there, it is always everywhere [...] in the entire universe (Boljkovac, 161). The two movies capture memory which transcends subjective borders and which focuses on the human nature. Memory implies action; as otherwise, like in nature, the grass will grow again as we distance ourselves from past events - as the movie Shoah by Lanzman depicts: in the opening scene, grass has grown to cover up the places subjected to death not so long ago. Memory is viewed as the medium through which we make justice to those whose faith has been decided beforehand as memory is expressive of the eternal return, the singularity of life through a creative forgetting of self (Boljkovac, 83).

Memory represents the way through which past and present communicate, identities are created and the process of becoming is made visible on screen: sheets of past and layers of reality correspond, emanating from an inside which is always already there, [...] gnawing at the present which is now only their encounter (Boljkovac,104). This is why memory relates to melancholia - characterized as the paradox of ephemeral, yet eternal sensation that lingers with us more than the event itself and shakes the coordinates of our world. Melancholia postulates an impossibility, the sense of something that has vanished, became unreachable, but touches us still nevertheless: [it] evokes both the before and after via the enduring prominence of the interstice or frontier itself, through which a direct presentation of time surfaces (Boljkovac, 120). Cinema is portrayed by Deleuze in a similar way, as he claims that cinematographic thought is brought face to face with its own impossibility, yet draws from it a higher power. Similarly, the heightened sensitivity emerges in Resnais' movies, brings about new possibilities, new deterritorializations which - as Rithy Panh suggests - plead that history is not to be repeated: Memory must remain a reference point. What I'm looking for is comprehension; I want to understand the nature of the crime [...] I want to avert repetition (37). In this way, time and duration acquire a new significance, as Deleuze and Guattari suggest: it will give sensation the power to exist and be preserved in itself in the eternity that coexists with this short duration (146).

It is on the surfaces of the bodies that become one with the earth and with the dust, that we realize the significance and the impact of our actions. The ultimate question regarding cinema is: what does it stand for? What happens at the intersection of haecceties, becomings, sensations and melancholia perpetuated at cinematographic level? To observe is to act, in the same way as Žižek claims that to be indifferent is also crime. In this respect, it is important to keep in mind the following line of thought which John Berger postulates in reference to Bruegel: Bruegel and Brecht [...] want the same thing understood: [...] that not to resist is to be indifferent, that to forget or not to know is also to be indifferent, and that to be indifferent is to condone (43). Derrida shows in The Spectres of Marx that the spectre - known as that which does not draw 
clear lines - poses a problem. Cinematography creates spectres, illusions, time and space and has the potential of re-writing history in the sense postulated by Rancière: focused on ordinary objects, on invisibility, so as to enable the creation of a people through cinematographic means, as Deleuze suggests.

\section{Works Cited}

Blanchot, Maurice, L'écriture du désastre. Gallimard, Paris. 1980. Translated by Ann Smock. Writing of a disaster. University of Nebraska Press, 1995.

Berger, John. Portraits. John Berger on Artists. Verso, 2017.

Bolijvak Nadine: Untimely affects Gilles Deleuze and an ethics of cinema. Edinburgh University Press, 2013.

Deleuze, Gilles and Félix Guattari. Mille Plateaux. Ed. de Minuit, 1998.

Derrida. The work of mourning. The University of Chicago Press, 2001.

Duras, Marguerite. Hiroshima mon amour, Richard Seaver (trans.). Grove Press, 1961.

Deleuze, Gilles. Cinéma 1. L'Image-Mouvement, Les Editions de Minuit, 1983.

Deleuze, Gilles. Cinéma 2, L'Image-temps. Les Editions de Minuit, 1985.

Gelman, Juan. Unthinkable tenderness. Translated by Joan Lindgren. University of California Press, 1997.

Kristeva, Julia. Pouvoirs de l'horreur, Ed. du Seuil, 1980. Translated by Leon S. Roudiez. Powers of Horror. An Essay on Abjection. Columbia UniversityPress, 1982.

Kristeva, Julia, Powers of horror. An Essay on Abjection. Pouvoirs de l'horreur Editions du Seuil, 1980, translated by Celine, Louis-Ferdinand, Columbia University Press. Surrey, 1982.

Loraine, Tasmine. Deleuze and Guattari's Immanent Ethics: Theory, Subjectivity, and Duration, State University of New York, 2011.

McLeary Richard. Signs. Northwestern University Press, 1960.

Rancière, Jacques. 2004. The Politics of Aesthetics, translated by Gabriel Rockhill. Continuum, 2004.

Ibidem. Le Partage du sensible: Esthétique et Politique. La Fabrique, 2000.

Raskin, Richard. Nuit et Brouillard by Alain Resnais: On the Making, Reception and Functions of a Major Documentary Film. Aarhus University Press, 1987.

Rhodes, Richard. The making of the atomic bomb. Simon and Schuster, 1986.

Montebello, Pierre. Philosophie et cinema. Librarie Philosophique, J. Vrin, 2008.

Spivak, Gayatri Chakravorty. An Aesthetic Education in the Era of Globalization. Harvard University Press, 2013.

Rithy, Panh. Elimination: a Survivor of the Khmer Rouge Confronts His Past and the Commandant of the killing fields. Other Press, 2012.

Ponty, Merleau Maurice. Le visible et l'invisible. Gallimard, 1964.

Ibidem. L'oeil et l'espirit. Gallimard, 1964.

Ted Toadvine and Leonard Lawlord, The Merleau Ponty Reader, Northwestern University Press, 2007. 
Williams, James. "Deleuze on J. M. W. Turner", in Deleuze and Philosophy: The Difference Engineer, Keith Ansell-Pearson (ed.). Routledge, 1997, 233-46.

\section{Filmography}

Nuit et Brouillard. Night and Fog. Alain Renais, France, 1955.

Hiroshima mon amour. Alain Resnais, France, 1959.

Ali:Fear eats the soul. Rainer Werner Fassbinder, Germany, 1974. 